\title{
Isolation of a New Virus from Chinook Salmon (Oncorhynchus tshawytscha) in Oregon U.S.A.*1
}

\author{
J. R. Winton*2, C. N. Lannan*2, D. P. Ransom*3, \\ and J. L. FRYER*2 \\ *2 Department of Microbiology, Oregon State University, \\ Corvallis, Oregon 97331 , U.S.A. \\ ${ }^{* 3}$ Oregon Aqua-Foods Inc., 88700 Marcola Road, \\ Springfield, Oregon 97478, U.S.A.
}

\begin{abstract}
A new virus has been isolated from adult chinook salmon (Oncorhynchus tshawytscha) in the state of Oregon, U.S.A. The virus was recovered from pooled kidney and spleen tissue samples using CHSE-214 cells. Cytopathic effect (CPE) required 28 days to develop on primary isolation. The virus replicated in CHSE-214, CHH-1, KO-6, CSE-119 and FHM cells. It had an optimal growth temperature of $18^{\circ} \mathrm{C}$ and no virus was produced at $24^{\circ} \mathrm{C}$ or above.

The virus was stable in minimal essential medium (MEM) at $\mathrm{pH} 3-11$ and replication was not affected in cells incubated with MEM containing $50 \mu \mathrm{g} / \mathrm{m} l$ iododeoxyuridine. Infectious virus was recovered from fractions of a $\mathrm{CsCl}$ gradient having a density of $1.20 \mathrm{~g} / \mathrm{cc}$. The agent was sensitive to chloroform and caused hemagglutination with erythrocytes from several species of fish, mammals and birds.

Electron microscopy revealed enveloped particles $125-250 \mathrm{~nm}$ in diameter containing a coiled nucleocapsid. Electron micrographs of freon-treated preparations showed the extracted nucleocapsid to be a helix $18 \mathrm{~nm}$ in diameter and up to $1000 \mathrm{~nm}$ in length. Based on morphology and biochemical features, the virus appears to be a member of the Paramyxoviridae.
\end{abstract}

\section{Introduction}

The use of certification examinations to control the spread of infectious diseases of fish has resulted in the discovery of several previously unknown viruses (KIMURA et al., 1981; SANO, 1976; WinTON et al., 1981). In recent years we have conducted viral examinations of sexually mature fish for the Oregon Department of Fish and Wildlife and for private aquaculture companies. Examinations of adult chinook salmon (Oncorhynchus tshawytscha) returning to the Yaquina River in the fall of 1982 and to the Trask River in 1983 have resulted in the isolation of a new virus of fish. In this paper we report our initial findings.

\section{Materials and Methods}

\section{Cells and Medium}

The virus was isolated using the chinook salmon

*1 Oregon Agricultural Experiment Station Technical Paper No. 7274. embryo cell line, CHSE-214 (ATCC CRL 1681). For propagating and assaying the virus we used the chum salmon heart cell line, CHH-1 (LANNAN et al., 1984). Growth studies were conducted using: CHSE-214, CHH-1, rainbow trout gonad (RTG-2; WOLF and QuimBY, 1962), atlantic salmon (AS; NiCHOLSON and BYRNE, 1973), brown bullhead (BB; Wolf and QuimBY, 1969), epithelioma papillosum cyprini (EPC; TOMASEC and FIJAN, 1977), fathead minnow (FHM; Gravell and Malsburger, 1965), kokanee salmon ovary (KO-6; LANNAN et al., 1984), and coho salmon embryo (CSE-119; FrYER et al., 1965). Methods for culturing fish cell lines have been described by WOLF and QUIMBY (1976). Eagle's minimal essential medium (MEM) was supplemented with $10 \%$ fetal bovine serum (MEM-10) for growing cells or 5\% (MEM-5) when replicating virus. Except where noted, cells were incubated at $18^{\circ} \mathrm{C}$.

\section{Virus Isolation}

The examinations of adult chinook salmon occur- 
red in the fall of 1982 at the Oregon Aqua-Foods Yaquina Bay recapture site, Lincoln County, Oregon, USA and in 1983 at the Oregon Department of Fish and Wildlife Trask River Hatchery, Tillamook County, Oregon, USA. The fish were sampled using standard methods outlined by the Fish Health Section of the American Fisheries Society (MCDANIEL, 1979). Kidney and spleen tissues and ovarian fluid samples were prepared in five-fish pools, inoculated onto monolayer cultures of CHSE-214 and EPC cells, and incubated at $18^{\circ} \mathrm{C}$. After 14 days, samples from these cultures were removed and inoculated onto a second set of the same cell lines. This "blind passage" was incubated for an additional 2 weeks.

\section{Virus Replication}

Monolayer cultures of CHH-1, CHSE-214, CSE119, AS, KO-6, FHM, EPC, BB, and RTG-2 cell lines were prepared in duplicate $25 \mathrm{~cm}^{2}$ flasks. The growth medium was removed and $5 \mathrm{~m} l$ MEM- 5 added to each flask. The cultures were inoculated with virus at a low multiplicity of infection (MOI), incubated at $18^{\circ} \mathrm{C}$, and observed daily for cytopathic effect (CPE). After 14 days, infectious virus in the culture fluid was assayed by calculating the $50 \%$ tissue culture infectious dose $\left(\mathrm{TCID}_{50}\right)$ using 96-well plates of $\mathrm{CHH}-1$ cells and the method of ReED and MuenCH (1938).

The optimal temperature for viral replication was measured using $75 \mathrm{~cm}^{2}$ flasks of $\mathrm{CHH}-1$ cells inoculated with virus at a low MOI. The cultures were incubated for 20 days at $6,9,12,15,18,21$, and $24^{\circ} \mathrm{C}$. At $48 \mathrm{hr}$ intervals, culture fluid was removed from the flasks at each temperature and the virus titer determined.

\section{Physical and Chemical Tests}

Thermostability of the agent was tested by incubating viral suspensions in MEM at 18,37 and $56^{\circ} \mathrm{C}$. Samples were removed at $1,6,24 \mathrm{hr}$ and 7 days. The $\mathrm{TCID}_{50}$ titer for each incubation period was determined using $\mathrm{CHH}-1$ cells.

The stability of the virus at selected $\mathrm{pH}$ values was measured by adding $0.5 \mathrm{~m} l$ culture fluid from infected CHH-1 cells to $4.5 \mathrm{ml}$ aliquots of MEM adjusted to $\mathrm{pH} 2,3,5,7,9$, and 11. After incubation for $30 \mathrm{~min}$ at $25^{\circ} \mathrm{C}$, the virus titer at each $\mathrm{pH}$ value was determined by $\mathrm{TCID}_{50}$ assay.

Chloroform sensitivity was tested using the method of FELDMAN and WANG (1961). One $\mathrm{m} l$ of chloroform was added to $2.0 \mathrm{~m} l$ of clarified culture fluid from infected $\mathrm{CHH}-\mathrm{l}$ cells. Control tubes received $1.0 \mathrm{~m} l$ of Hanks' balanced salt solution (BSS). The cultures were shaken for $10 \mathrm{~min}$, centrifuged $(2000 \mathrm{~g}, 10 \mathrm{~min})$, and the virus titers determined for the BSS and chloroform-treated preparations. Infectious hematopoietic necrosis virus, known to have a lipid-containing envelope (PILCHER and FrYer, 1980), and the non-enveloped, infectious pancreatic necrosis virus (MCALLISTER, 1979) were included as controls.

Membrane filters of $1.2,0.45$ and $0.2 \mu$ pore size were pretreated with $10 \%$ fetal bovine serum and used to filter a viral suspension. The titers before and after filtration were calculated by $\operatorname{TCID}_{50}$ assay using $\mathrm{CHH}-1$ cells.

The effect of the DNA virus inhibitor 5-iodo-2'deoxyuridine (IDU) was tested by the method of KUCHLER (1977). Replicate $25 \mathrm{~cm}^{2}$ flasks of $\mathrm{CHH}-1$ cells containing MEM-5 or MEM-5 with $50 \mu \mathrm{g}$ $\mathrm{IDU} / \mathrm{m} l$ were inoculated with virus. Oncorhynchus masou virus (OMV), a herpesvirus containing a DNA genome (KIMURA et al., 1981) and infectious pancreatic necrosis virus (IPNV), a birnavirus with an RNA genome (MCAlLISTER, 1979) were included as controls. After incubation at $18^{\circ} \mathrm{C}$ for 10 days, the $\mathrm{TCID}_{50}$ titers in the IDU-treated and untreated flasks were determined for each virus.

\section{Density of the Virus in Cesium Chloride}

Culture fluid from virus-infected $\mathrm{CHH}-1$ cells was clarified by low speed centrifugation $(2000 \mathrm{~g}$, $10 \mathrm{~min}$ ) and the virus in the supernate collected by centrifugation at $100,000 \mathrm{~g}$ for $1 \mathrm{hr}$ in an SW 28 rotor. The viral pellet was resuspended in $0.5 \mathrm{ml}$ BSS and layered onto a three-step gradient composed of $1.5 \mathrm{~m} l 40 \% \mathrm{w} / \mathrm{w} \mathrm{CsCl}, 1.5 \mathrm{~m} / 30 \%$ w $/ \mathrm{w}$ $\mathrm{CsCl}$ and $1.5 \mathrm{~m} / 20 \% \mathrm{w} / \mathrm{w} \mathrm{CsCl}$. The gradient was centrifuged in an SW 50.1 rotor at $115,000 \mathrm{~g}$ for $16 \mathrm{hr}$ and $0.25 \mathrm{~m} /$ fractions collected ' with a probe and peristaltic pump. The refractive index of each fraction was read and the density calculated by interpolation from the International Critical Tables. The titer of infectious virus in alternate fractions was determined by TCID $_{50}$ assay.

\section{Hemagglutination Assay}

Culture fluid from infected $\mathrm{CHH}-1$ cells was clarified by low speed centrifugation, the virus 
collected by centrifugation for $1 \mathrm{hr}$ at $100,000 \mathrm{~g}$, and the pellet resuspended in BSS. Suspensions of human (A, B and O), rabbit, guinea pig, horse, sheep, pig, bovine, goat, turkey, chicken, steelhead trout, chinook, coho, and chum salmon erythrocytes were prepared in phosphate buffered saline. Rapid slide hemagglutination tests were performed by reacting $50 \mu \mathrm{l}$ of a $10 \%$ suspension of erythrocytes with $100 \mu \mathrm{l}$ of partially purified virus or with BSS. A microtiter hemagglutination test was performed by the method described in KUCHLER (1977).

\section{Negative Staining of Virions}

Culture fluid from infected $\mathrm{CHH}-1$ cells was clarified by low speed centrifugation $(2000 \mathrm{~g}$, $10 \mathrm{~min}$ ) and the virus pelleted in an SW 28 rotor at $100,000 \mathrm{~g}$ for $1 \mathrm{hr}$. The pellet was resuspended in distilled water, stained with $2 \%$ phosphotungstic acid for $1 \mathrm{~min}$ and examined using a Philips 300 electron microscope. In certain preparations, infected cell homogenates were first treated with Genetron (1,1,2-Trichlorotrifluoroethane) to remove cell debris.

\section{Examination of Infected Cells}

Monolayer cultures of $\mathrm{CHH}-1$ cells were infected at an MOI of approximately 1.0 and the cells incubated at $18^{\circ} \mathrm{C}$ for $2,3,4,5$, or 7 days before fixation with $3 \%$ glutaraldehyde in BSS. The fixed cells were scraped from the flasks and pelleted by centrifugation at $500 \mathrm{~g}$ for $5 \mathrm{~min}$. Cells were stained for $1 \mathrm{hr}$ with $1 \%$ osmium tetraoxide, passed through a dehydration series and embedded in Spurr's medium (SPURR, 1969). Sections were cut with an ultramicrotome, post-stained with lead citrate (REYNolds, 1963) and examined by electron microscopy.

\section{Results}

\section{Isolation of Virus}

The CHSE-214 and EPC cells used in the virus assay remained normal in appearance during the initial 14 day incubation. Samples from these cultures were removed and inoculated onto a second set of the same cell lines. On day 14 of this "blind pass", cytopathic effect began to appear in the cultures of CHSE-214 cells containing kidney and spleen homogenates. Cultures containing ovarian fluid samples and all EPC cells remained normal.
Samples were removed from the CHSE-214 cells showing CPE, passed through a $0.45 \mu$ membrane filter and subcultured on CHSE-214 cells where CPE reappeared after approximately 10 days. Early cytopathology was composed of a cluster of 3-10 cells becoming refractile and rounded. With further incubation, CPE became generalized, involving the entire cell sheet (Fig. 1). Later, cells detached from the surface of the flasks and floated free in the medium.

\section{Virus Replication}

Of the cell lines tested, the virus replicated and produced $\mathrm{CPE}$ in $\mathrm{CHH}-1, \mathrm{CHSE}-214, \mathrm{KO}-6$ and CSE-119 cells. In these cell lines the average titers ranged from $3.2 \times 10^{5}$ to $5.2 \times 10^{6} \mathrm{TCID}_{50} / \mathrm{m} /$. The FHM cell line produced a low titer of virus $\left(3.0 \times 10^{2} / \mathrm{ml}\right)$ without CPE. When CHH-1 cells were infected at a low MOI and incubated at selected temperatures, viral synthesis was optimal at $18^{\circ} \mathrm{C}$ but occurred from $6-21^{\circ} \mathrm{C}$ (Table 1). No virus was produced at $24^{\circ} \mathrm{C}$ and cytopathic effect was only observed in cultures incubated between $15-21^{\circ} \mathrm{C}$. These data suggest that the host range of the virus is confined to cold blooded animals.

\section{Physical and Chemical Features}

The virus remained viable after exposure to $18^{\circ} \mathrm{C}$ for 7 days, but was completely inactivated after $6 \mathrm{hr}$ at $56^{\circ} \mathrm{C}$ or $24 \mathrm{hr}$ at $37^{\circ} \mathrm{C}$ (Table 2). No reduction in titer occurred after a freeze-thaw cycle at -20 or $-70^{\circ} \mathrm{C}$.

Infectious virus passed membrane filters with pore sizes of $1.2,0.45$ or $0.2 \mu$. The unfiltered suspension contained $3.2 \times 10^{5} \mathrm{TCID}_{50} / \mathrm{ml}$. Passage through a $1.2 \mu$ filter reduced the titer to $6.3 \times 10^{4}$. After the $0.45 \mu$ membrane, the titer was $3.2 \times 10^{3}$ and following the $0.2 \mu$ filter, it was only $3.2 \times 10^{1}$ $\mathrm{TCID}_{50} / \mathrm{m} l$. These results might be expected if infectious particles had an irregular shape or varied in size.

The virus was not affected by incubation for $30 \mathrm{~min}$ in MEM-5 at $\mathrm{pH} 3,5,7,9$ or 11 . However, no infectious virus remained after exposure to $\mathrm{pH} 2$ for $30 \mathrm{~min}$.

Chloroform completely inactivated the virus (Table 3). Control suspensions treated with BSS had a titer of $3.2 \times 10^{5} \mathrm{TCID}_{50} / \mathrm{m} l$. Inactivation of the virus by chloroform indicates the complete virion has an envelope containing essential lipids. 


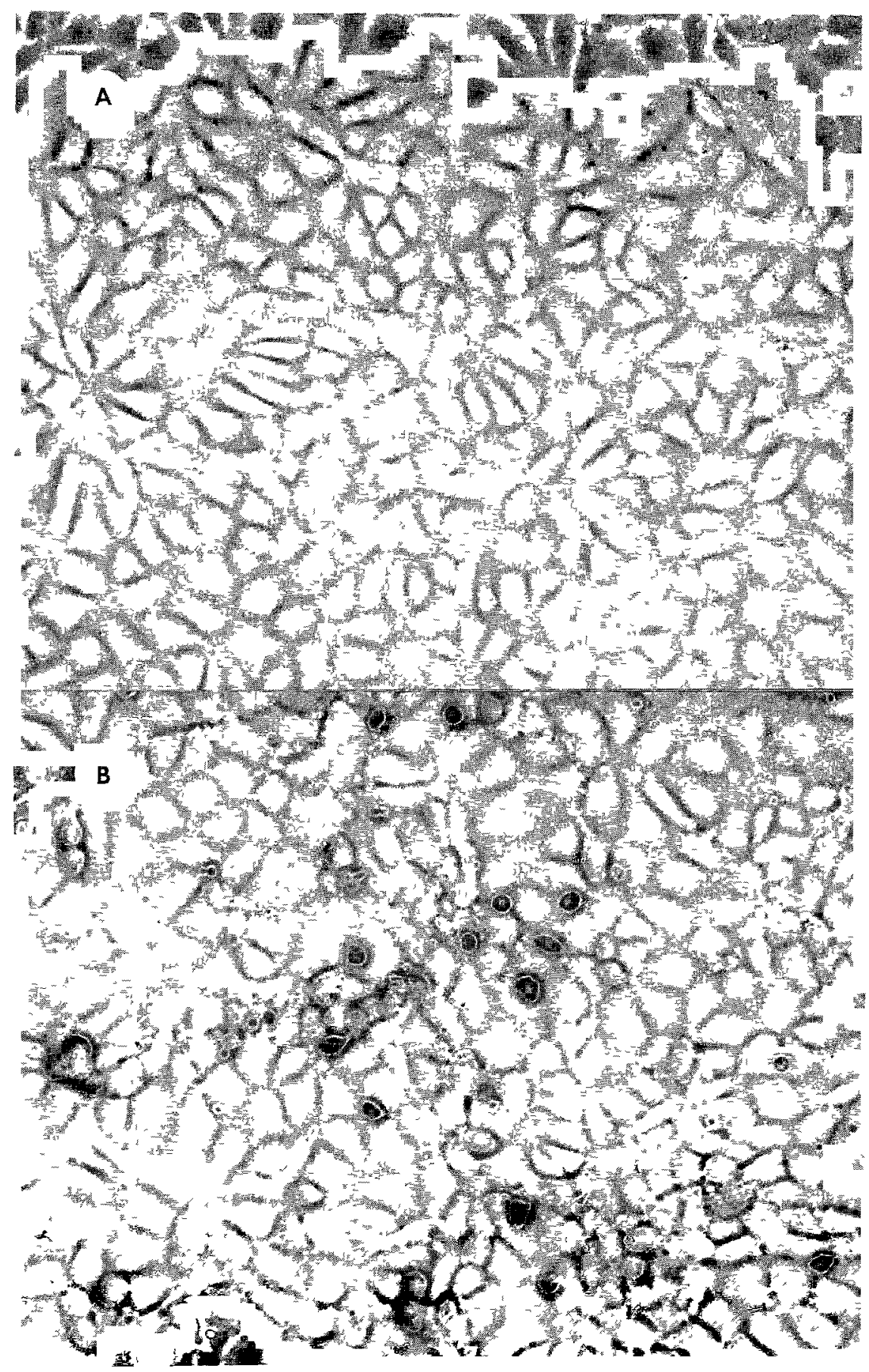

Fig. 1. Cytopathic effect produced in a monolayer culture of the chum heart cell line ( $\mathrm{CHH}-1)$ by the virus solated from chunook salmon A Normal cell monolayer B Infected culture 
Table 1. Replication of the virus isolated from chinook salmon in the chum heart cell line (CHH-1) incubated at seven selected temperatures

\begin{tabular}{cccccccccccc}
\hline \hline \multirow{2}{*}{$\begin{array}{c}\text { Temperature } \\
\left({ }^{\circ} \mathrm{C}\right)\end{array}$} & \multicolumn{8}{c}{} & \multicolumn{7}{c}{$\log _{10} \mathrm{TCID}_{50} / \mathrm{ml}$ at days post-infection } \\
\cline { 2 - 10 } & 2 & 4 & 6 & 8 & 10 & 12 & 14 & 16 & 18 & 20 \\
\hline 6 & 0.0 & 0.0 & 0.0 & 0.0 & 2.5 & 3.4 & 3.8 & 3.5 & 4.0 & 4.6 \\
9 & 0.0 & 0.0 & 0.0 & 0.0 & 3.5 & 3.5 & 4.3 & 3.8 & 4.5 & 4.8 \\
12 & 0.0 & 0.0 & 0.0 & 2.8 & 3.4 & 3.6 & 3.8 & 5.6 & 4.8 & 4.8 \\
15 & 0.0 & 0.0 & 0.0 & 2.6 & 4.5 & 4.8 & 5.0 & 6.0 & 5.8 & 5.8 \\
18 & 0.0 & 0.0 & 2.3 & 3.3 & 4.8 & 5.3 & 4.7 & 5.5 & 7.0 & 5.6 \\
21 & 0.0 & 2.0 & 2.0 & 2.6 & 3.8 & 4.3 & 5.3 & 5.5 & 5.5 & 5.5 \\
24 & 0.0 & 0.0 & 0.0 & 0.0 & 0.0 & 0.0 & 0.0 & 0.0 & 0.0 & 0.0 \\
\hline
\end{tabular}

Table 2. Stability of the virus isolated from chinook salmon exposed to three selected temperatures in minimal essential medium

\begin{tabular}{ccccc}
\hline \hline \multirow{2}{*}{$\begin{array}{c}\text { Temperature } \\
\left({ }^{\circ} \mathrm{C}\right)\end{array}$} & \multicolumn{4}{c}{ Titer $\left(\mathrm{TCID}_{50} / \mathrm{m} /\right)^{\mathrm{a}}$} \\
\cline { 2 - 5 } & $1 \mathrm{hr}$ & $6 \mathrm{hr}$ & $24 \mathrm{hr}$ & 7 days \\
\hline 18 & $\mathrm{ND}^{\mathrm{b}}$ & $\mathrm{ND}$ & $3.2 \times 10^{6}$ & $3.2 \times 10^{6}$ \\
37 & $1.0 \times 10^{7}$ & $4.0 \times 10^{5}$ & 0.0 & 0.0 \\
56 & $1.0 \times 10^{4}$ & 0.0 & 0.0 & 0.0 \\
\hline
\end{tabular}

a Initial titer was $2.0 \times 10^{6}$.

b Not determined.

Table 3. Stability of the virus isolated from chinook salmon to treatment with chloroform for $30 \mathrm{~min}$

\begin{tabular}{ccc}
\hline \multirow{2}{c}{ Virus } & \multicolumn{2}{c}{ Titer $\left(\mathrm{TCID}_{50} / \mathrm{m} l\right)$} \\
\cline { 2 - 3 } & Treated & Untreated \\
\hline $\begin{array}{c}\text { Chinook salmon isolate } \\
\text { Infectious pancreatic } \\
\text { necrosis virus }\end{array}$ & 0.0 & $3.2 \times 10^{5}$ \\
$\begin{array}{c}\text { Infectious hematopoietic } \\
\text { necrosis virus }\end{array}$ & $1.0 \times 10^{\mathrm{b}}$ & $6.3 \times 10^{8}$ \\
\hline
\end{tabular}

a Control virus lacking essential lipids.

b Control virus containing essential lipids.

Infectious hematopoietic necrosis virus, the enveloped control, was also inactivated by chloroform. Infectious pancreatic necrosis virus which lacks essential lipids was unaffected.

Treatment of cells with iododeoxyuridine did not affect viral synthesis (Table 4). Replication of the DNA virus control (OMV) was completely blocked
Table 4. Replication of the virus isolated from chinook salmon in the chum heart cell line (CHH-1) with growth medium containing $50 \mu \mathrm{g} / \mathrm{m} l 5$ iodo-2'-deoxyuridine

\begin{tabular}{|c|c|c|}
\hline \multirow{2}{*}{ Virus } & \multicolumn{2}{|c|}{ Titer $\left(\mathrm{TCID}_{50} / \mathrm{m} l\right)$} \\
\hline & Treated $^{a}$ & Untreated ${ }^{b}$ \\
\hline Chinook salmon isolate & $4.0 \times 10^{7}$ & $4.0 \times 10^{6}$ \\
\hline $\begin{array}{l}\text { Infectious pancreatic } \\
\text { necrosis virus }\end{array}$ & $4.0 \times 10^{9}$ & $2.0 \times 10^{9}$ \\
\hline Oncorhynchus masou virus ${ }^{\mathrm{d}}$ & 0.0 & $6.3 \times 10^{5}$ \\
\hline
\end{tabular}

a Cells were grown and virus replicated using minimal essential medium containing $5 \%$ serum (MEM-5) and $50 \mu \mathrm{g} / \mathrm{m} / 5$-iodo-2'-deoxyuridine.

b Cells were grown and virus replicated in MEM-5 without iododeoxyuridine.

c Control virus with RNA genome.

d Control virus with DNA genome.

while the RNA virus control (IPNV) was not. The lack of inhibition by halogenated thymidine analogs is considered presumptive evidence that a virus possesses an RNA genome (REVOzzo and BURKE, 1973; KUCHLER, 1977).

\section{Density of the Particles}

Infectious virus was recovered from fractions near the center of the $\mathrm{CsCl}$ equilibrium gradient. The virus did not form a visible band and the titer was low. When infectious virus was assayed by $\mathrm{TCID}_{50}$ and plotted against the density of each fraction, a peak of infectivity was found in fractions having a density of $1.20 \mathrm{~g} / \mathrm{m} /$. 


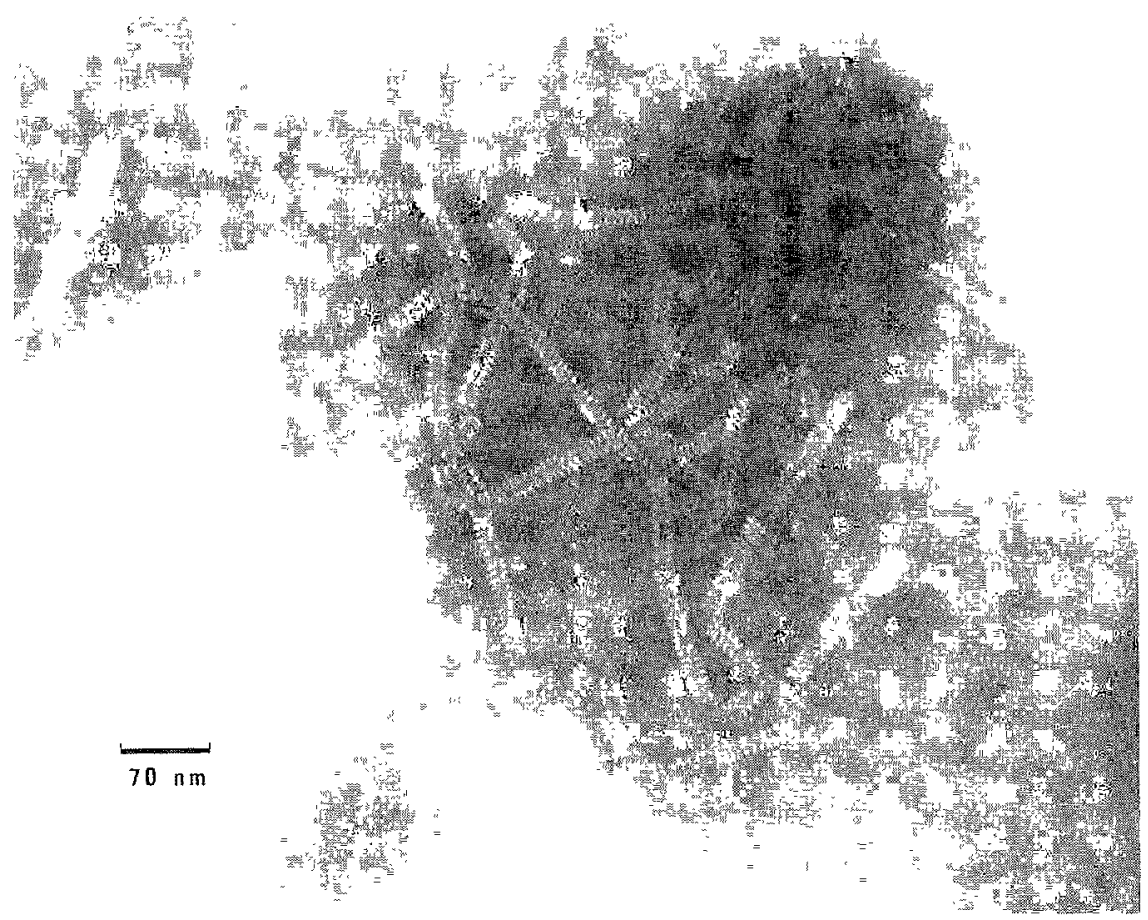

Fig. 2. Electron micrograph of negatively stained nucleocapsids showing the helical structure.

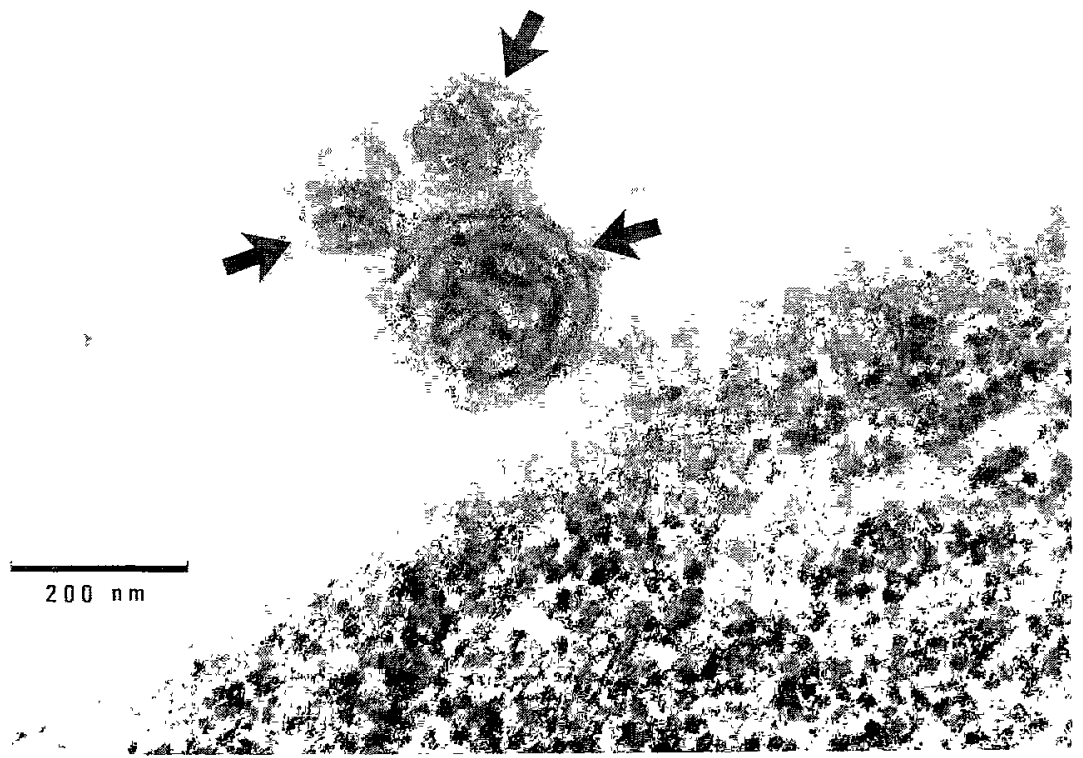

Fig. 3. Electron micrograph of a thin section of infected $\mathrm{CHH}-1$ cells showing enveloped particles (arrows) containing coiled nucleocapsids. 


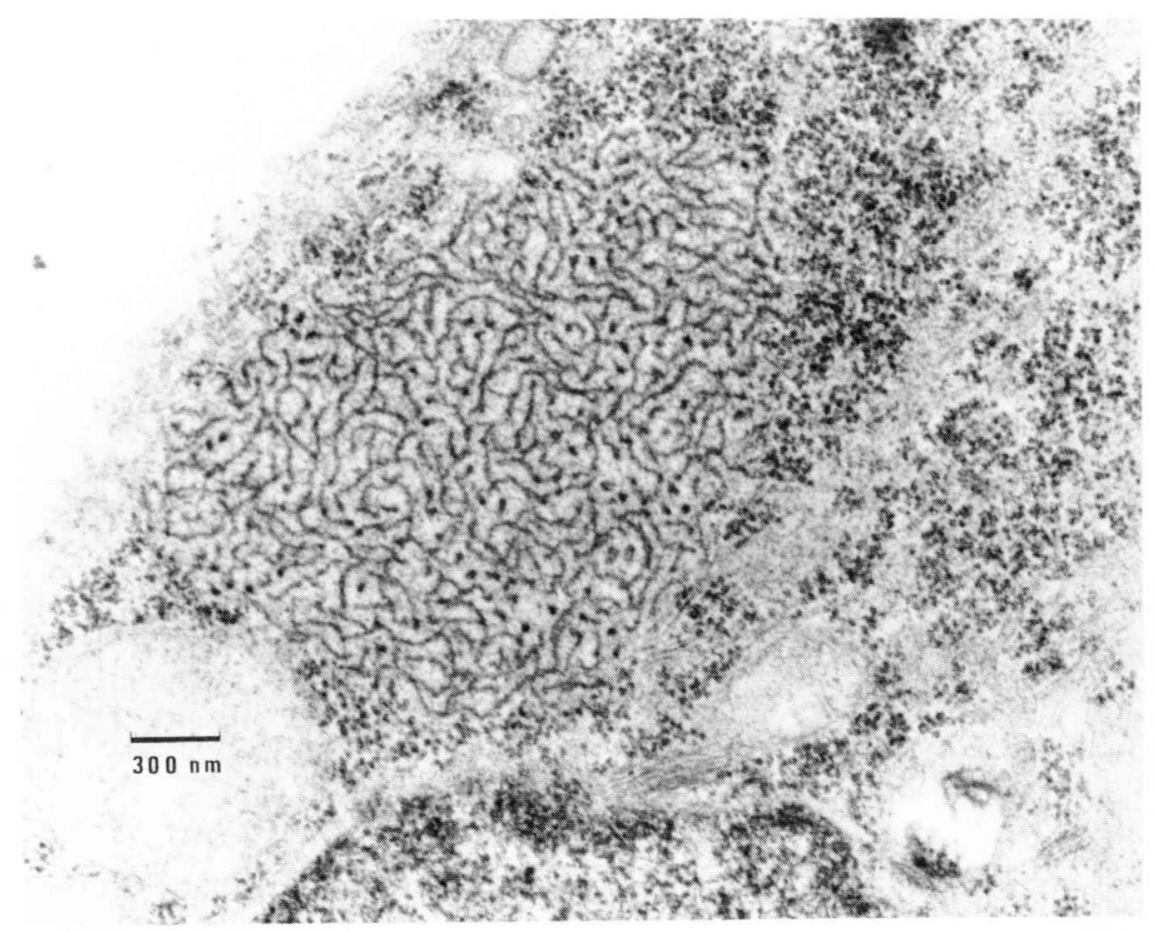

Fig. 4. Electron micrograph of a thin section through an infected $\mathrm{CHH}-1$ cell showing many nucleocapsids in the cytoplasm.

\section{Hemagglutination}

The virus caused rapid hemagglutination of erythrocytes from 11 of the 14 species of mammals, birds and fish tested. Agglutination was not observed using sheep, goat or bovine cells. The end points of the hemagglutination titers were similar for the 11 types of reacting cells. Agglutination of the fish erythrocytes was particularly rapid.

\section{Virus Morphology}

Negatively stained preparations of Genetrontreated and partially purified cell culture fluid revealed helical nucleocapsids approximately $18 \mathrm{~nm}$ in diameter and up to $1000 \mathrm{~nm}$ in length (Fig. 2). The nucleocapsid appeared to be a left-handed helix containing a $5 \mathrm{~nm}$ central pore. The capsomeres slanted slightly toward one end.

Thin sections of CHH-1 cells infected for $72 \mathrm{hr}$ showed enveloped viral particles that varied in size between 125 and $250 \mathrm{~nm}$. The virions were not regular in shape and could be seen to contain coiled nucleocapsids (Fig. 3). The particles were present in groups and appeared to have matured by budding through the cell membrane. Areas containing large numbers of nucleocapsids were observed in the cytoplasm of infected cells (Fig. 4).

\section{Discussion}

The isolation and characterization of this virus has been hindered because the agent produces CPE slowly and the titers obtained from cultured cells are low. While the virus has been isolated in consecutive years from fish in two separate river systems, the origin and distribution of the agent is not known. The extended length of time required to produce viral CPE on initial isolation may have allowed the virus to go undetected until now. Morphologically and chemically, both isolates appear the same. Serological analysis in progress will test their relatedness.

The isolates were obtained from infected adult chinook salmon showing no signs of gross pathology. Attempts were made to recover the virus from progeny of the Yaquina Bay stock without success. Pathogenicity trials are in progress using four spe- 
cies of salmonid fish and both isolates of the virus.

The results reported here indicate the virus is an enveloped particle of approximately $125-250 \mathrm{~nm}$ in diameter containing a coiled helical nucleocapsid. The genome of the agent is believed to be RNA. The virus hemagglutinates the erythrocytes of a number of animals including fish. It replicates in cell lines derived from Pacific salmon at an optimal temperature of $18^{\circ} \mathrm{C}$ and is stable at $\mathrm{pH} 3-11$. The infectious virion has a density of $1.20 \mathrm{~g} / \mathrm{m} /$ in $\mathrm{CsCl}$.

We believe that this agent is a previously undescribed virus of fish. Chemical and morphological features suggest that the virus is a member of the family Paramyxoviridae (CHOPPIN and Compans, 1975; Kingsbury, 1977). Further work will be required before precise taxonomic placement of this new fish virus can be made.

\section{Acknowledgements}

The authors thank Ms. Chris Weiss for her excellent assistance with the electron microscopy portion of this study. This work was conducted at the Oregon State University Marine Science Center and is a result of research sponsored by NOAA Office of Sea Grant, Department of Commerce, under Grant No. NA81AA-D-00086 and the National Science Foundation U.S.-Japan Cooperative Science Program Grant No. INT8210495. The U.S. Government is authorized to produce and distribute reprints for governmental purposes, not withstanding any copyright notation that may appear hereon.

\section{References}

Choppin, P. W. and R. W. Compans (1975): Reproduction of paramyxoviruses. In $\mathrm{H}$. Fraenkel-Conrat and $\mathrm{R}$. Wagner (eds.), Comprehensive Virology, Vol. 4. Plenum, New York, 95-178.

Feldman, H. and S. Wang (1961): Sensitivity of various viruses to chloroform. Proc. Soc. Exp. Biol. Med., 106, 736-738.

Fryer, J. L., A. Yusha, and K. S. Pilcher (1965): The in vitro cultivation of tissue and cells of Pacific salmon and steelhead trout. Ann. N. Y. Acad. Sci., 126, 566-586.

Gravell, M. and R. G. Malsburger (1965): A permanent cell line from the fathead minnow (Pimephales promelas). Ann. N. Y. Acad. Sci., 126, 555-565.
Kimura, T., M. Yoshimizu, M. TAnaKa, and H. SAnnohe (1981): Studies on a new virus (OMV) from Oncorhynchus masou I. Characteristics and pathogenicity. Fish Pathol., 15, 143-147.

Kingsbury, D. W. (1977): Paramyxoviruses. In D. Nayak (ed.), The Molecular Biology of Animal Viruses. Marcel Dekker, New York, 349-382.

KuCHLER, R. J. (1977): Biochemical Methods in Cell Culture and Virology. Dowden, Hutchinson and Ross, Stroudsburg, $331 \mathrm{p}$.

Lannan, C. N., J. R. Winton, and J. L. Fryer (1984): Fish cell lines: Establishment and characterization of nine cell lines from salmonids, In Vitro, 20, 671-676.

MCAllister, P. E. (1979): Fish viruses and viral infections. In H. Fraenkel-Conrat and R. R. Wagner (eds.), Comprehensive Virology, Vol. 14. Plenum, New York, 401-470.

MCDaniel, D. (ed.) (1979): Procedures for the Detection and Identification of Certain Fish Pathogens. American Fisheries Society, Bethesda, 117 p.

NiChOlsON, B. L. and C. BYRNE (1973): An established cell line from the Atlantic salmon (Salmo salar). J. Fish. Res. Board Can., 30, 913-916.

PILCher, K. S. and J. L. Fr Yer (1980): The viral diseases of fish: a review through 1978. CRC Critical Reviews in Microbiology, 7, 287-364.

ReED, J. L. and H. Muench (1938): A simple method of estimating fifty percent endpoints. Am. J. Hyg., 27, 493-497.

ReYNolDS, E. S. (1963): Use of lead citrate at high pH as an electron opaque stain in electron microscopy. J. Cell Biol., 17, 203-212.

Rovozzo, G. C. and C. N. Burke (1973): A Manual of Basic Virological Techniques. Prentice-Hall, Englewood Cliffs, 287 p.

SANO, T. (1976): Viral diseases of cultured fish in Japan. Fish Pathol., 10, 221-226.

SPURR, A. R. (1969): A low viscosity epoxy resin embedding medium for electron microscopy. J. Ultrastructure Res., 26, 31-43.

TOMASEC, J. and N. FiJAN (1971): Virusne bolesti riba (viral diseases of fish). Final report on research under a part of Project 6/1966. Zagreb.

Winton, J. R., C. N. Lannan, J. L. Fryer, and T. KIMURA (1981): Isolation of a new reovirus from chum salmon in Japan. Fish Pathol., 15, 155-162.

Wolf, K. and M. C. QUimBY (1962): Established eurythermic line of fish cells in vitro. Science, 135, 1065-1066.

Wolf, K. and M. C. Quimby (1969): Fish cell and tissue culture. In W. S. Hoar and D. J. Randall (eds.), Fish Physiology. Academic Press, New York, 253-305.

Wolf, K. and M. C. Quimby (1976): Procedures for subculturing fish cells and propagating fish cell lines. Tissue Culture Association Manual, 2, 471-474. 